\title{
Chronic Hepatitis B Virus Infection and Pregnancy
}

\author{
Manoj Kumar^, Tarandeep Singh ${ }^{\star \star}$, Swati Sinha* \\ *Department of Obstetrics and Gynecology, Sitaram Bhartia Institute of Science and Research, B-16, Qutab Institutional Area, New Delhi \\ 110016, "* Department of Hepatology, Institute of Liver and Biliary Sciences, D-1, Vasant Kunj, New Delhi 110070, India
}

\begin{abstract}
Planning of pregnancy and management of chronic hepatitis B virus during pregnancy includes recognition of maternal virological status, assessment of liver disease severity and minimization of risk for mother to infant transmission of infection. Decisions regarding the use of antivirals during pregnancy need to be individualized. Monitoring for infection and immunization in newborns is also important. For mothers on antiviral therapy, breastfeeding is not recommended. (J Clin EXP Hepatol 2012;2:366-381)
\end{abstract}

A pproximately 400 million people are chronically infected with hepatitis B virus (HBV) worldwide, ${ }^{1}$ and almost half have acquired their infections either through mother to infant transmission or in early childhood, especially in countries where HBV has intermediate to high prevalence. ${ }^{2}$ In Asia, $8 \%-10 \%$ of the population is chronically infected with HBV, and up to $50 \%$ of new cases of hepatitis $B$ infection are due to mother to infant transmission. ${ }^{3}$ In contrast, the majority of new hepatitis B cases in developed countries are the result of horizontal transmission in adulthood. Before the adoption of standard passive-active immunoprophylaxis treatment, approximately $70 \%-90 \%$ of infants born to hepatitis B surface antigen (HBsAg) and hepatitis B e antigen (HBeAg) positive mothers became chronically infected with HBV. ${ }^{4}$ The mother to infant transmission rate was reduced to $5 \%-10 \%$ when infants received appropriate postnatal hepatitis B immunoglobulin (HBIg) and a series of HBV vaccines. However, despite passive-active immunoprophylaxis provided to infants, up to $8 \%-30 \%$ of infants born to highly viremic mothers still become infected with HBV (Figures 1-3).

This review will address several issues important to chronic hepatitis B virus infection and pregnancy includ-

Keywords: pregnancy, chronic hepatitis B, breast feeding Received: 14.7.2012; Accepted: 6.9.2012; Available online: 20.9.2012 Address for correspondence: Manoj Kumar, Department of Hepatology, Institute of Liver and Biliary Sciences, D-1, Vasant Kunj, New Delhi 110070, India.

E-mail: manojkumardm@gmail.com

Abbreviations: HBV: hepatitis B virus; HBsAg: hepatitis B surface antigen; HBeAg: hepatitis B e antigen; HBIg: hepatitis B immunoglobulin; ALT: alanine aminotransferase; APR: Antiretroviral Pregnancy Registry; DART: Development of Antiretroviral Therapy Study; HIV: human immunodeficiency virus; CDC: Centers for Disease Control and Prevention; PHACS: Pediatric HIV/AIDS Cohort Study; RCTs: randomized clinical trials; FDA: Food and Drug Administration; ECS: elective caesarian section; CI: confidence interval; EASL: European Association for the Study of the Liver; NA: nucleot(s)ide analog; PEG-IFN: pegylated interferon; APASL: Asian Pacific Association for the Study of the Liver http://dx.doi.org/10.1016/j.jceh.2012.09.001 ing effect of pregnancy on chronic HBV infection, effect of chronic HBV infection on pregnancy, mother to infant transmission, safety data on HBV antivirals during pregnancy, management of chronic HBV infection in women who desire pregnancy or become pregnant while taking antivirals.

\section{PREVALENCE OF CHRONIC HEPATITIS B VIRUS INFECTION AMONG PREGNANT WOMEN IN INDIA}

The prevalence of chronic HBV infection varies widely, with rates ranging from $0.1 \%$ to $20 \%$ in different parts of the world. "High" prevalence (HBsAg positivity rates > 8\%) regions include the Asia (except Japan), parts of the Middle East, sub-Saharan Africa, and the Amazon basin. "Intermediate" ( $2 \%-7 \%$ HBsAg positive) prevalence regions include, the Indian subcontinent, parts of central Asia and the Middle East, Eastern and Southern Europe, as well as parts of South America. "Low" prevalence ( $<2 \% \mathrm{HBsAg}$ positive) regions include the United States, Northern Europe, Australia, Japan and the southern part of South America. Overall, $45 \%$ of the world population lives in "high" prevalence regions.

The HBsAg positivity rate of Hepatitis B in India is different in the different regions of the country. The overall chronic HBsAg positivity rate is often quoted as being $4.7 \% .^{5}$ In India, the prevalence rate of HBsAg positivity in pregnant women in studies before 1990s varies from 2.6 to $9.5 \%,{ }^{6-11}$ whereas more recent studies have reported HBsAg positivity among pregnant women ranging from 0.8 to $1.1 \%{ }^{12-14}$ The HBeAg positivity among HBsAg positive pregnant women have varied widely from $4.8 \%$ to $68.7 \%{ }^{6,14}$ In a recent study from Delhi, which found HBsAg prevalence of $1.1 \%$ among pregnant women, it was found that the alanine aminotransferase (ALT) levels were normal in $54 \%$ of the women and HBV DNA levels were above 10,000 copies $/ \mathrm{mL}(2000 \mathrm{IU} / \mathrm{ml})$ in $71 \%$ of women. The median HBV DNA levels were higher in women who were $\mathrm{HBeAg}$ positive compared to the 


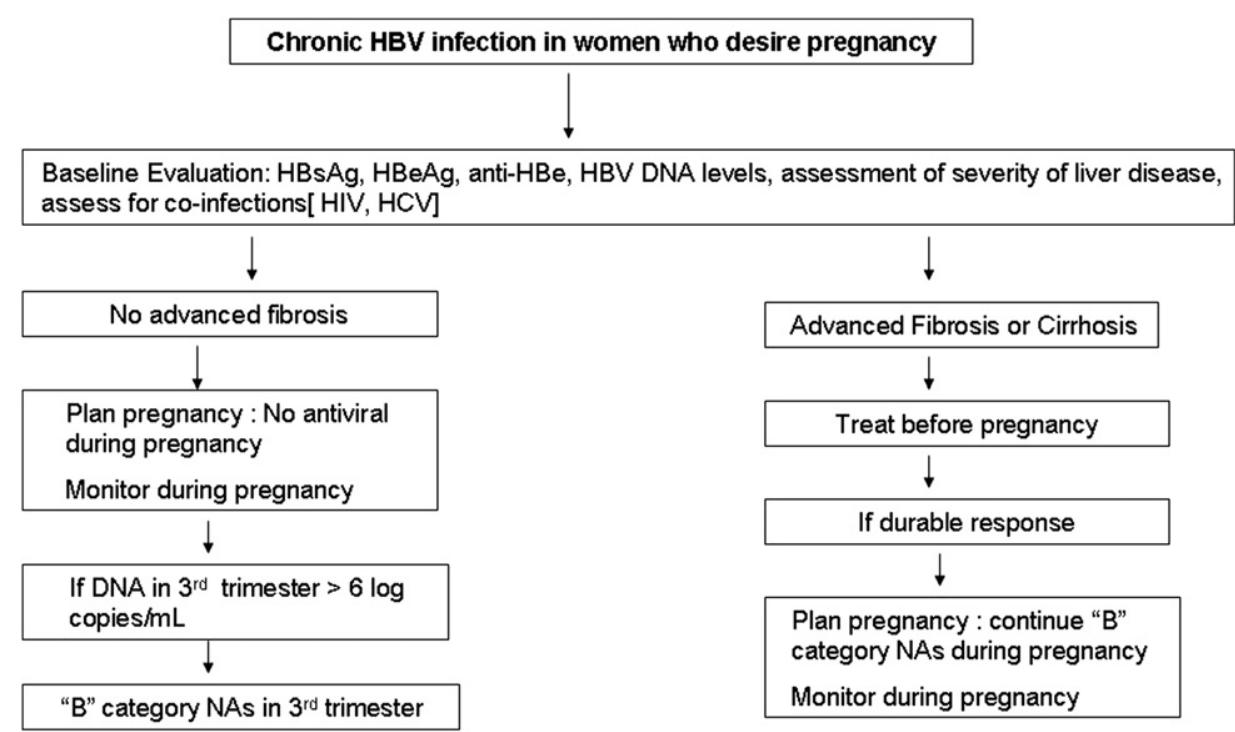

Figure 1 Suggested management of chronic HBV infection in women who desire pregnancy.

HBeAg-negative group. The most common HBV genotype was D $(84 \%)$ followed by A + D and A (8\% each). ${ }^{14}$

\section{EFFECT OF PREGNANCY ON CHRONIC HEPATITIS B VIRUS INFECTION}

No worsening of liver disease occurs in the majority of women during pregnancy and liver enzymes frequently normalize. However, case reports of hepatic exacerbations/fulminant hepatic failures in HBsAg-positive pregnant women have been reported. ${ }^{15,16}$

A proportion of women have hepatitis flares with or without $\mathrm{HBeAg}$ seroconversion (12.5-17\%) within the first months after delivery. ${ }^{17-19}$ Among HBeAg positive chronic HBV-infected mothers, low HBeAg titers and low HBV
DNA viral loads have been associated with HBeAg loss after delivery. ${ }^{19}$ In a recent study from Netherlands, among pregnant patients with chronic HBV infection, there was an overall increase in median HBV DNA levels during pregnancy, which declined after pregnancy. Median ALT values also decreased during pregnancy and a significant increase in liver disease activity after pregnancy, defined as a three times increase in alanine aminotransferase (ALT) within 6 months after delivery, occurred in $45 \%$ of patients. ${ }^{17}$ It is important to appreciate the variability in the clinical manifestation of acute flares of chronic hepatitis B during the peri-partum period. It may range from mild flare to severe flares and even leading to death or requiring liver transplant. ${ }^{20,21}$

$\mathrm{HBV}$ is a noncytopathic virus and the associated hepatic inflammation is mainly mediated by the host's immune

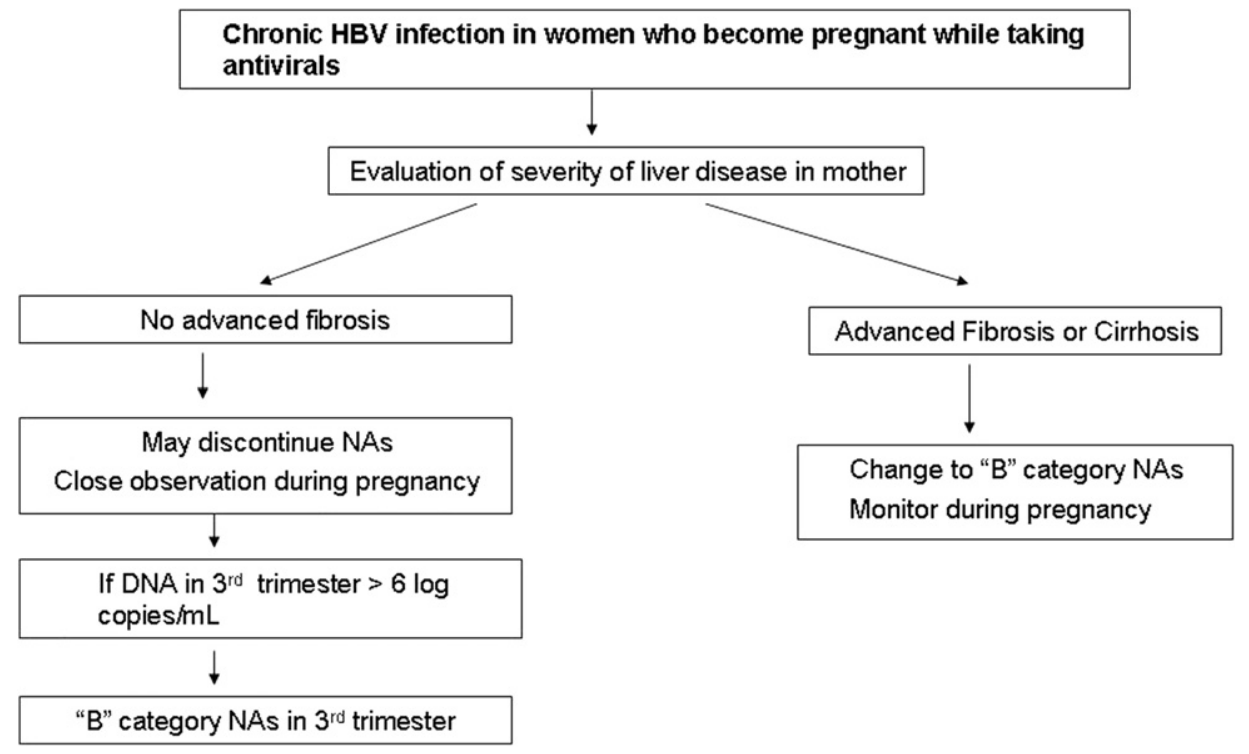

Figure 2 Suggested management of chronic HBV infection in women who become pregnant while taking antivirals. 


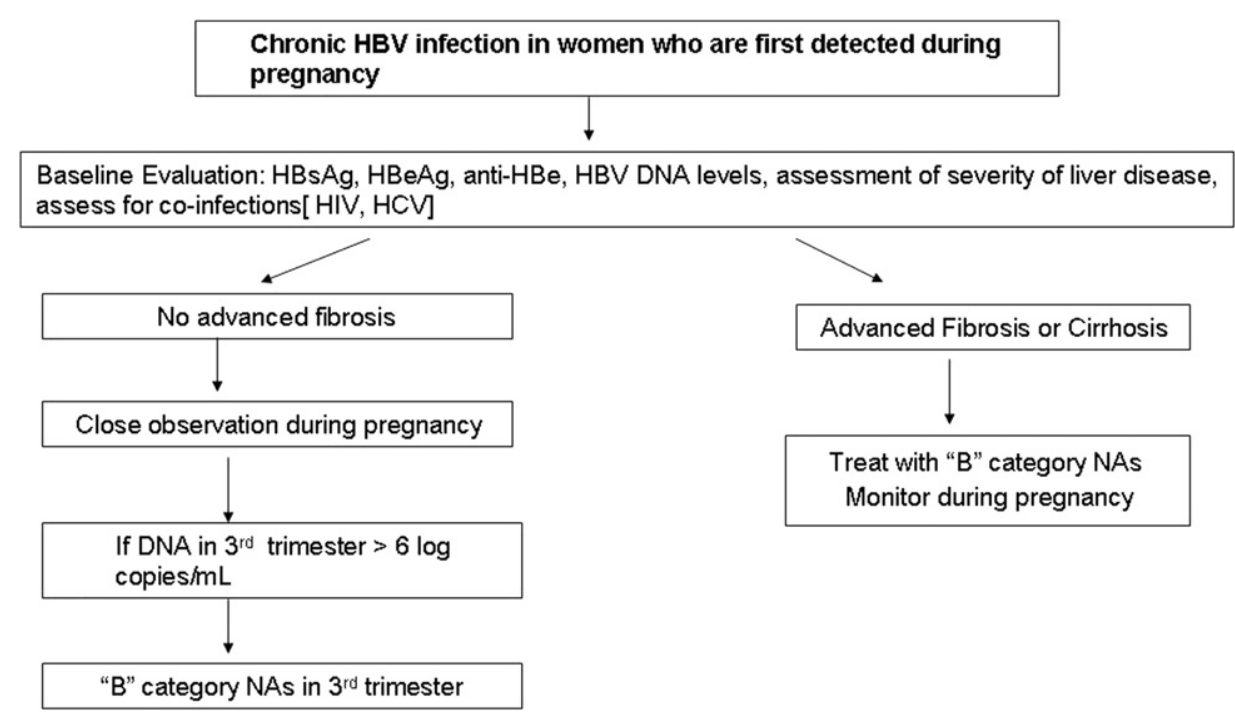

Figure 3 Suggested management of chronic HBV infection in women who are first detected during pregnancy.

response. In patients with chronic HBV infection an inadequate immune response of the host plays an important role in the development of chronicity. ${ }^{22}$ During pregnancy, there are numerous alterations in the maternal immune system to prevent rejection of the fetus. ${ }^{23}$ Several factors are produced by both the fetal trophoblast and the maternal uterine tissue like CD95L (Fas ligand), indoleamine 2, 3 -dioxygenase and leukemia inhibitory factor; also there is a shift in the T helper cells (TH1-TH2) balance toward a TH2 response with increased amounts of regulatory $\mathrm{T}$ cells (contributing to an inadequate immune response against the virus). ${ }^{24}$ All these changes in the immune status recover after delivery and the immune system fully restores its function. The reactivation of the immune system is responsible for the high amount of patients with a post pregnancy increase in ALT. ${ }^{17}$ It is thus prudent to monitor HBV-infected women closely for several months after delivery for hepatitis flares and seroconversion.

\section{EFFECT OF CHRONIC HEPATITIS B VIRUS INFECTION ON PREGNANCY}

Many reports are available with varied results on the effects of chronic HBV infection on the outcome of pregnancy. Although few reports found no association of HBV infection with adverse pregnancy outcomes in chronically HBVinfected mothers, a few studies from Hong Kong and Israel have found that chronic HBV-infected mothers have increased risk for threatened preterm labor and preterm delivery. ${ }^{25,26}$ However, these studies did not assess maternal HBeAg status or serum or cord blood HBV DNA levels during pregnancy. One recent study from Greece, showed a significant association between spontaneous preterm birth and presence of HBV DNA in the cord blood. HBV DNA positivity in cord blood was significantly associated with maternal HBV DNA levels. ${ }^{27}$ Many studies have suggested the use of nucleos $(t)$ ide analog therapy with an appropriate anti-HBV agent for managing HBV infection in mothers whose serum tests positive for HBsAg and who have high serum HBV DNA concentrations in last trimester. ${ }^{28}$ Whether the use of antiviral agents in chronic HBVinfected mothers with high serum HBV DNA concentrations throughout or during the last trimester of pregnancy, could result in lower obstetric complications including preterm birth is an interesting area. ${ }^{29}$

\section{MOTHER TO INFANT TRANSMISSION}

\section{Definitions}

Mother to infant transmission (also known as vertical transmission or perinatal transmission) is the transmission of an infection or other disease from mother to child immediately before and after birth. Transmission might occur either while the baby is still in the uterus (prenatal, antepartum, in utero or intrauterine transmission), during the delivery process (natal or intrapartum transmission), or shortly after birth (postpartum or during child care or through breast milk) [see below]. Although the transmission of infections from mother to infant is popularly known as perinatal infection; it is not synonymous to infections during the perinatal or neonatal period. Perinatal period is an interval extending approximately from the 28 th week of gestation to the 28th day after birth. Therefore, by definition, in utero infections in the first or second trimester of pregnancy are not considered as perinatal infection. Therefore, the term perinatal transmission may 
be avoided and instead use the term mother to infant transmission or vertical transmission. ${ }^{24}$

For a newborn infant whose mother is positive for both $\mathrm{HBsAg}$ and $\mathrm{HBeAg}$, the risk for chronic HBV infection is $70 \%-90 \%$ by age 6 months in the absence of post exposure immunoprophylaxis. For infants of women who are HBsAg positive but HBeAg negative, the risk for chronic infection is $<10 \%-40 \%$ in the absence of post exposure immunoprophylaxis. $85-95 \%$ of infected infants will become chronic HBV carriers. Rare cases of fulminant hepatitis B among perinatally infected infants also have been reported. Mother to infant transmission, mainly from HBeAg negative, HBsAg positive mothers, is the most important route of transmission for acute or fulminant hepatitis in infancy. ${ }^{24,30}$ The incidence of fulminant hepatitis $B$ is higher in infancy than in other age periods. ${ }^{30}$

\section{Risk Factors for Mother to Infant Transmission Hepatitis B e Antigen Status of Mother}

HBeAg may be filtered through the placenta. ${ }^{31}$ Although, maternal HBeAg positivity has been suggested as an independent risk factor for mother to infant transmission, ${ }^{32}$ this finding has not been confirmed by other studies. ${ }^{33,34}$ In a study from China, in 54 mother-infant pairs (33 mothers were $\mathrm{HBeAg}$ positive, and $21 \mathrm{HBeAg}$ negative; all babies received passive-active immunoprophylaxis with hepatitis B immune globulin and hepatitis B vaccine), $70 \%(23 / 33)$ of neonates from HBeAg-positive mothers were $\mathrm{HBeAg}$ positive at birth compared with $0 \%(0 / 21)$ of neonates from $\mathrm{HBeAg}$-negative mothers. $\mathrm{HBeAg}$ was present at higher titer in the birth sera of the babies with HBV breakthrough than in babies without breakthrough. $\mathrm{HBeAg}$ was cleared from the serum in all 19 babies without breakthrough. In 17 of these 19 babies, the HBeAg was cleared within 6 months, and in two babies clearance took 12 months. The mean serum HBV DNA level in the mothers of the infants with HBV breakthrough was significantly higher than in the mothers of babies who did not become infected. ${ }^{35}$ Thus, he study concluded that HBeAg can cross the human placenta, and disappears from serum within 6 months in most babies. HBV DNA levels in hepatitis $B$ infected mothers are associated with the failure of HBIg and vaccine immunization [see below], and the additional influence of transmitted HBeAg cannot be excluded.

Among HBeAg-positive mothers, lower Hepatitis B core (anti-HBc) titers were associated with a higher incidence of mother to infant transmission. A high maternal anti-HBc level in serum may be a negative predictor of immunoprophylaxis failure in high-risk infants. ${ }^{36}$

\section{Hepatitis B Virus Deoxyribonucleic Acid}

Serum HBV DNA level has been identified as the single most important predictor and independent risk factor for mother to infant transmission. Earlier studies found that prophylaxis effective rate of passive-active immunoprophylaxis is approximately $100 \%$ if maternal prelabor HBV DNA levels were $<5.5 \log 10$ copies $/ \mathrm{mL}$, as compared with $2 / 3$ rd of cases if maternal DNA levels were more than these levels. ${ }^{37,38}$ One Canadian study found that the maternal HBV DNA level of $>8 \log 10 \mathrm{IU} / \mathrm{mL}$ was associated with increased likelihood of immunoprophylaxis failure. ${ }^{39} \mathrm{An}$ other study from Australia found that the risk of mother to infant transmission increased with maternal HBV DNA levels $>8 \log 10$ copies $/ \mathrm{mL}$ and no transmission was seen in babies of mothers with HBV DNA levels $<8 \log 10$ copies $/ \mathrm{mL} .{ }^{33}$ However, till recently it was not clear whether lower levels of maternal HBV DNA may have a significant impact on immunoprophylaxis failure. A recent large study on more than a thousand mother-infant pairs from China demonstrated that immunoprophylaxis failure only occurred in infants born to HBeAg-positive mothers. When maternal predelivery HBV DNA levels were stratified to <6 $\log 10$ copies $/ \mathrm{mL}, \quad 6-6.99 \quad \log 10$ copies $/ \mathrm{mL}$, 7-7.99 $\log 10$ copies $/ \mathrm{mL}$, and $\geq 8 \log 10$ copies $/ \mathrm{mL}$, the corresponding rates of immunoprophylaxis failure were $0 \%$, $3.2 \%, 6.7 \%$, and $7.6 \%$, respectively $(P<0.001) .{ }^{34}$ One Indian study found that $\mathrm{HBV}$ transmission (detection of any of the HBsAg, HBeAg, or HBV DNA in cord blood or peripheral blood of neonates) occurred in $78 \%$ of cases with maternal HBV DNA levels $\geq 1.5 \times 10^{5}$ copies/mL as compared with $47 \%$ in cases with maternal HBV DNA levels $<1.5 \times 10^{5}$ copies $/ \mathrm{mL}^{40}$ Thus, the maternal HBV DNA level of $>6 \log 10$ copies $/ \mathrm{mL}$ at delivery seems to be the most important predictor for MTCT. There is a nonlinear correlation between infant and maternal HBV DNA levels in the prophylaxis failed group indicating that increased maternal-fetal gradient across the placenta is not playing a part in transmission. ${ }^{41}$ There is a suggestion that high levels of maternal HBV DNA may enhance HBV transmission to embryos. ${ }^{42}$

\section{HBV Genotypic Variations}

Eight genotypes of HBV have been defined (forms A-H). Different genotypes are distributed in different geographical areas. For example, genotypes $\mathrm{B}$ and $\mathrm{C}$ are prevalent in Asia, while genotypes A and D are more common in Europe, the Middle East and India. The prevalence among pregnant women reflects their distribution in general population in that particular region. Genotype can be a factor associated with viral load and frequency of vertical transmission. For example, despite similar high prevalence of HBV chronic carriers, the rate of maternofetal infection in east Asia, particularly China, was estimated to range between 10 and $88 \%,{ }^{43,44}$ compared with $8 \%$ or less in studies conducted in sub-Saharan Africa. ${ }^{45,46}$ This difference can be largely attributed to the natural history of $\mathrm{HBV}$ infection of genotype B and C, as in south-east Asia where infected individuals carry HBeAg and high viral load in age 
groups that include most women of gestational age. ${ }^{46,47}$ In contrast, in sub-Saharan Africa, whether infected with $\mathrm{HBV}$ genotype $\mathrm{A} 1$ or $\mathrm{E}$, seroconversion to anti-HBe occurs before age 15 or 16 , with the consequence that most women of gestational age carry anti-HBe. ${ }^{48}$ In a study, there was no particular HBV genotype (genotypes B and $\mathrm{C}$ were included in the study) significantly associated with the loss of HBeAg among the mothers after delivery. ${ }^{19}$ In a study from Japan, the relationship between routes of HBV transmission and HBV genotypes was studied in 118 children (98\% had chronic HBV infection, and 2\% had acute hepatitis). Genotype C (86\%) was the most frequent, followed by genotype B (9\%), D (2.5\%), and A (1.0\%). Transmission routes of HBV to children were from mothers in 91 patients (77\%), fathers in 8 (6.5\%), mother or father in 1 (1\%), family members other than the parents in 5 (4\%), and unknown in 13 (11.5\%). Eighty-eight (97\%) of 91 children of mother to infant transmission were genotype C, while 13 (49\%) of 27 children of the routes other than the mother to infant transmission were genotype $\mathrm{C}$. The number of children with genotype $\mathrm{C}$ who were infected from their mothers was significantly higher than those with genotype B, D, or A $(P<0.01){ }^{49}$ However, other studies have not found any association between HBV genotype and vaccination failure. ${ }^{50,39}$ However, due to specific distribution of genotypes in particular areas, and lack of studies on comparative role of different HBV genotypes in transmission of hepatitis B virus to offspring, further studies are warranted to define the role of HBV genotypes in mother to infant transmission.

The role of mutants in $S$ gene (which might occur naturally or after vaccination) in vaccine failure remains inconclusive. Recent studies showed no difference between success and failure groups to immunoprophylaxis in terms of mutation rate, but the mutation distributions differ. In a study from China, 41 mothers from whom HBV transmission to their children was prevented were compared with 37 mothers whose children were HBsAg positive 1 year after $\mathrm{HBV}$ vaccination. Although the DNA loads in mothers of the failure group were significantly higher than those in the success group; no difference was found in the $\mathrm{S}$ gene mutation rate and genotypes between the groups. Interestingly, Thr123Ala and Gly145Arg were observed only in failure-group mothers, whereas Thr126Asn, Thr126Ser, Thr143Asn, Asp144Gly, and Asp144Ala were seen in the success group. Thus, high viral load is an important risk factor for HBV vaccination failure, which is correlated with the positions of mutations in the $S$ gene, but not with mutant frequencies or genotypes. ${ }^{50} \mathrm{HBIg}$ does not play a role in the development of S mutants. ${ }^{39}$

The role of precore and basal core mutations in mother to infant transmission has not yet been fully explored, although infants born to mothers with HBV precore mutations may be more likely to have HBeAg-negative fulminant hepatitis if mother to infant transmission occurred. ${ }^{51}$

\section{Occult Hepatitis B Virus Infection}

Occult HBV infection is the long-lasting persistence of viral genomes in the liver tissue (and in some cases also in the serum) of individuals negative for the HBsAg by currently available assays. ${ }^{52,53}$ In woodchucks, mothers with occult woodchuck hepatitis virus transmitted virus to their offspring. ${ }^{54}$ Vertical transmission of occult HBV from pregnant woman to the fetus has also been described. ${ }^{55}$ One Korean study on 202 healthy pregnant women, where HBV DNA testing was performed using two specific quantitative tests with two independent sets of sera and cord blood, found that 8 of 202 (4\%) individuals with the TaqMan PCR assay and 23 of 202 (11.4\%) with the COBAS Amplicor HBV Monitor test were HBV DNA positive. Six (3\%) individuals were positive with both methods. Cord blood obtained from four of six individuals who were positive with both the HBV DNA methods, was HBV DNA negative. ${ }^{56}$ Thus, the vertical transmission of occult $\mathrm{HBV}$ infection through cord blood although possible is not so high as to be a clinical problem, but warrants further investigation in population-based studies.

\section{Routes of Mother to Infant Transmission}

There are three possible routes of transmission of HBV from infected mothers to infants: prenatal (antepartum or in utero or intrauterine), natal transmission (intrapartum or during delivery) or postnatal (Postpartum or during child care or through breast milk) transmission.

\section{Prenatal (Antepartum or In Utero or Intrauterine) Transmission}

At present, the combined immunity of hepatitis $B$ vaccine and high-titer hepatitis B immunoglobulin (HBIg) has already achieved relatively excellent efficacies in blocking the maternal-infant transmission of HBV. However, still among around $10 \%$ of the mothers with positive HBV serum marker, the immunological blockade failed in the born neonates who later became chronically infected with HBV. In clinical practice, the tests of HBsAg and HBV DNA in fetal cord blood or neonatal peripheral blood are often performed to diagnose intrauterine HBV infection. ${ }^{57}$ Neonatal peripheral blood is better than cord blood for diagnosis of intrauterine infection as the possibility of the cord blood being contaminated by the maternal blood always remains. ${ }^{29}$ Intrauterine transmission is defined as detectable HBV DNA in neonatal peripheral venous blood. $^{58}$

It is currently thought that the major cause of unsuccessful immunological blockade is the prenatal or intrauterine transmission of HBV. The mechanisms of such an infection include:

1) Placental infection and transplacental transmission of HBV 
Intrauterine $\mathrm{HBV}$ infection is mainly transmitted through the placenta from the maternal blood to the fetus. Transfer of HBV from cell to cell in the placenta has been suggested by a decreasing titer of $\mathrm{HBcAg}$ and HBsAg from the maternal to fetal side. ${ }^{58} \mathrm{HBV}$ can infect all kinds of cells in placenta, with HBV transmission occurring either by $\mathrm{HBV}$-infected cells from maternal decidua to villous capillary endothelia or by HBV-infected trophoblastic cells directly to villous mesenchymal cells and villous capillary endothelial cells. ${ }^{59}$ High level of serum HBV DNA in pregnant women is one of the high-risk factors for occurrence of HBV intrauterine infection [see above].

\section{2) Transplacental leakage of maternal blood}

Threatened preterm labor or spontaneous abortion, with the possible mixing of maternal and fetal blood, appears to increase the risk of $\mathrm{HBV}$ transmission. ${ }^{60}$

\section{3) Amniocentesis}

Every genetic amniocentesis theoretically inoculates the intrauterine cavity with maternal blood because the needle traverses the abdominal and uterine wall. In fact, visible intrauterine bleeding can be seen in up to $38 \%$ of genetic amniocentesis procedures that do not involve the placenta. ${ }^{61}$ However, amniocentesis has not been shown to significantly increase mother to infant transmission rates in published studies, ${ }^{62-64}$ that were mainly based on infants' HBsAg status without HBV DNA testing.

\section{4) Other mechanisms}

HBV can circulate to the fetus via maternal peripheral blood mononuclear cells. ${ }^{65}$ Intrauterine transmission might also occur via oocytes or sperms in HBV-infected persons. ${ }^{62}$

Recently, polymorphisms in some cytokine genes, such as those encoding for interferon- $\gamma$ and tumor necrosis factor $\alpha$, have been correlated with risk of intrauterine infection with HBV. ${ }^{43,66}$

\section{Natal (Intrapartum) Transmission}

It is widely accepted that most mothers to infants transmission occurs at or near the time of birth (natal transmission), because neonatal vaccination prevents newborn infection in about $80-95 \%$ of cases. Theoretical risks for HBV transmission at delivery include maternal-fetal microtransfusion during delivery or swallowing of infective fluid. A linear association was observed between the duration of the first stage (stronger association if duration $>9 \mathrm{~h}$ ) and the presence of HBV antigens in cord blood. ${ }^{67}$ Partial placental leakage occurring during labor, trauma from instrumentation, and threatened preterm labor can result in the mixing of fetal and maternal circulation (microtransfusion) and lead to an increase in the risk of HBV infection. HBsAg and HBV DNA has been detected in vaginal epithelial cells, cervicovaginal cells, amniotic fluid and vaginal fluid samples of HBsAg positive mothers during preg- nancy, ${ }^{67,68}$ raising the possibility that direct contact with the infective fluid in the maternal genital tract might also be responsible for the transmission of $\mathrm{HBV}$ to infants.

\section{Postnatal (Postpartum) Transmission}

Breastfeeding has been a major concern in postpartum HBV transmission because HBsAg has been detected in breast milk in a large proportion of $\mathrm{HBV}$-infected women. ${ }^{67}$ In addition, HBsAg can be transmitted to the infant via abrasions around the mother's nipple, although mother to infant transmission via this route is difficult to prove, as person-to-person transmission of HBV usually takes prolonged periods of close contact. After the availability of immunization, there was concern about the risk that breastfeeding might confer. However, studies have documented no difference in rates of perinatal infection between breastfed and formula-fed vaccinated infants. ${ }^{69,70}$ Thus $\mathrm{HBV}$ infection is not considered a contraindication to breastfeeding of infants who receive the HBIg and HBV vaccine. ${ }^{71}$ Breastfeeding does not interfere with the immune response to the $\mathrm{HBV}$ vaccine. ${ }^{72}$

\section{SAFETY DATA ON HEPATITIS B VIRUS ANTIVIRALS DURING PREGNANCY}

Safety data on HBV antivirals during pregnancy come from two major sources: the Antiretroviral Pregnancy Registry (APR), ${ }^{73}$ and the Development of Antiretroviral Therapy Study (DART).$^{74}$ The APR is an international, voluntary, prospective exposure registration cohort study of women exposed to antiretroviral therapies, most of whom are HIV-1 monoinfected. As of January 2012, data from 16,732 pregnancies (including 203 HBV monoinfected) were available. No significant difference has been reported in the rate of adverse outcomes if the initial exposure of any $\mathrm{HBV}$ drug was in the first trimester $(2.7 \%)$ compared to the second or third trimester $(2.5 \%)$ of pregnancy; which compares favorably to the $2.72 \%$ reported by the CDC birth defect surveillance system. However, APR only provided short-term prospective observational data on birth defects, but potential other side effects of antiretroviral agents and side effects occurring later in life in the child, are not available in the APR. Child's long-term safety from the usage of antiviral agents during pregnancy has not yet been established.

The DART study is a multicenter, randomized trial of antiretroviral therapy among adults with symptomatic HIV-1 infection or advanced disease/AIDS in Africa. The $3 \%$ rate of congenital anomalies reported in this study also compares favorably to the $2.72 \%$ reported by the CDC birth defect surveillance system. ${ }^{74}$

\section{Lamivudine}

In pregnant women, lamivudine crosses the placenta readily by simple diffusion. ${ }^{75}$ In a study of 57 HIV-infected 
pregnant women receiving lamivudine as part of antiretroviral therapy, maternal blood, cord blood and amniotic fluid samples correlated with fetal concentrations; and the median concentration in the amniotic fluid was 5 times higher than in maternal plasma. ${ }^{76}$ Animal teratogenicity studies have been performed in rats and rabbits with exposure up to 40 and 36 times higher than human doses, respectively, with no observed teratogenicity. There was, however, a reduction in litter size of rabbits observed at exposures less than that observed at human clinical dosage. ${ }^{77}$

Lamivudine is a pregnancy category $\mathrm{C}$ medication for HBV (Table 1). Its safety profile has been documented in human immunodeficiency virus (HIV) or HBV co-infected pregnant mothers in the APR. ${ }^{73}$ The infant birth defect rates for lamivudine exposure at the first and second/third trimesters were $127 / 4088$ [3.1\% (95\% CI: $2.6 \%-3.7 \%$ )] and 186/6635 [2.8\% (95\% CI: $2.4 \%-3.2 \%)]$ respectively, which did not differ from those born to mothers without exposure to antiviral therapy. This statistic compares favorably to the $2.72 \%$ rate reported by the Centers for Disease Control and Prevention (CDC) birth defect surveillance system. There have been concerns about long-term carcinogenicity in children exposed to lamivudine in utero or postpartum. A recently reported prospective cohort found cancer incidence in 8853 children (median age 5.4 years) exposed to $\geq 1$ antiretroviral drug (5908 received Lamivudine) during pregnancy or postpartum. ${ }^{78}$ The incidence did not differ significantly from the general population, with 10 tumors detected. Prematurity and exposure to the combination of didanosine/lamivudine remained independently associate

Table 1 Pregnancy category of FDA-approved treatments for chronic HBV.

\begin{tabular}{lc}
\hline Drug & Pregnancy category \\
\hline IFN alpha & C \\
\hline Peg-IFN alpha & $\mathrm{C}$ \\
Adefovir & $\mathrm{C}$ \\
Entecavir & $\mathrm{C}$ \\
Lamivudine & $\mathrm{C}$ \\
\hline Telbivudine & $\mathrm{B}$ \\
\hline Tenofovir & $\mathrm{B}$ \\
\hline
\end{tabular}

Category A drugs: controlled studies in women fail to demonstrate a risk to the fetus.

Category B drugs: no teratogenic/embryogenic risk in animal studies and no controlled human studies available or risk in animal studies, but controlled human studies refute these.

Category C drugs: teratogenic/embryocidal effects in animals, and no controlled studies in humans.

Category D drugs: positive evidence of human fetal risk, but benefits from use in pregnant women may be acceptable despite the risk.

Category $\mathbf{X}$ drugs: positive evidence of human fetal risk and the risk of the use in pregnant women clearly outweighs any possible benefit. with cancer, but the authors advised that long-term surveillance is warranted. ${ }^{78}$

Thus of all the antivirals active against HBV, lamivudine has the most safety data in pregnancy.

\section{Tenofovir}

Studies on placental transfer of tenofovir (usually in association with other antiretroviral drugs) performed in HIVinfected women have reported a median ratio of maternal to umbilical cord concentration of $1.00,{ }^{79}$ thus exposing infants to relatively high levels in utero. Reproductive toxicity studies in rats and rabbits did not reveal harmful effects to fetus at concentrations of 4-13 and 66 times higher than human exposure levels, respectively. ${ }^{80}$ In studies on gravid rhesus monkeys administered tenofovir subcutaneously once daily from 20 to 150 days of gestation, there was normal fetal development, although overall body weights and crown-rump lengths were less than those fro age matched controls, along with a small reduction in fetal bone porosity. ${ }^{81,82}$

Tenofovir is a pregnancy category B medication. It has been safely used in pregnant women with HIV (some with HBV co-infection). The birth defects rates were 31/1370 [2.3\% (95\% CI: 1.5\%-3.2\%)] during first trimester exposure and $18 / 782$ [2.3\% (95\%CI: 1.4\%-3.6\%)] during second/third trimester exposure, which did not significantly differ from those without tenofovir exposure. ${ }^{73}$ Safety issues for tenofovir-exposed infants include concerns about congenital abnormalities, renal function, bone mineralization, and growth. These concerns first arose from studies showing that high doses of tenofovir given to pregnant rhesus macaques caused bone demineralization, impaired somatic growth, and low levels of insulin-like growth factor-1 in their infants. ${ }^{81,82}$ Renal tubular leak of phosphate resulted in bone demineralization and deformities in macaque infants given high dose tenofovir, although these effects were largely reversible once tenofovir was stopped. ${ }^{83}$ Despite increasing numbers of infants being exposed to tenofovir in utero and use of off-label tenofovir in HIV-infected children, data on its effects on renal function, bone mineralization, and growth remain relatively sparse; in particular, few studies have included a control group. A recent report from DART study found no evidence of increased renal impairment or hypophosphataemia among infants exposed in utero to tenofovir- versus non-tenofovir-containing Antiretroviral therapy (ART) ${ }^{74}$ whereas, other studies have found decreased bone mineral density and hypophosphataemia in children receiving tenofovir versus controls. ${ }^{84,85}$ Although abnormalities appear to normalize following withdrawal of tenofovir, more longterm data are needed in children receiving tenofovir from an early age. Longer term data on bone health in both tenofovir-exposed HIV-infected children and infants exposed to in utero tenofovir are needed. With respect to 
growth among tenofovir-exposed infants, the US Pediatric HIV/AIDS Cohort Study (PHACS) of 532 infants reported lower weight but not height at $1 \mathrm{y}$ among those exposed versus not exposed to tenofovir in utero, although the effect was unrelated to duration of tenofovir exposure and was not present at birth. ${ }^{86}$ The authors concluded that tenofovir should remain an "alternative" rather than "recommended" drug during pregnancy as per current US guidelines. ${ }^{87}$

\section{Telbivudine}

In preclinical animal studies, telbivudine crossed placenta in rats, but did not demonstrate any teratogenicity or carcinogenicity in rats or rabbits at doses 6 times-37 times higher than therapeutic human doses. ${ }^{88}$ An increase in premature delivery and abortion was observed in rabbits at plasma levels 37 times higher than those in humans at therapeutic dose. ${ }^{88}$ Although telbivudine is a pregnancy category B medication, the safety data for telbivudine in the APR remain limited. Telbivudine has been used in pregnant women with no significant adverse effects in infant [see below].

Although the safety data of telbivudine seems promising, however there is small experience in pregnant women and thus more clinical experience is required in pregnant women.

\section{Entecavir}

There is no data regarding placental transfer of entecavir. There were no signs of embryofetal or maternal toxicity when pregnant animals received oral entecavir at approximately 28 (rat) and 212 (rabbit) times the human exposure achieved at the highest recommended human dose of $1 \mathrm{mg} /$ day. In rats, maternal toxicity, embryofetal toxicity (resorptions), lower fetal body weights, tail and vertebral malformations, reduced ossification (vertebrae, sternebrae, and phalanges), and extra lumbar vertebrae and ribs were observed at exposures 3100 times those in humans. In rabbits, embryofetal toxicity (resorptions), reduced ossification (hyoid), and an increased incidence of 13th rib were observed at exposures 883 times those in humans. Entecavir was carcinogenic in both mice and rats. An increase in incidence of lung and other tumors were observed after long-term exposure in rats and mice. ${ }^{89}$ There are few case reports in the APR on entecavir (44 cases). ${ }^{73}$ Further cases of entecavir exposure are required to detect an increase in fetal malformations compared with the background rate in the population.

\section{Adefovir Dipivoxil}

No increase in tumor incidence has been reported in carcinogenicity studies in mice and rats at 10 and 4 times human doses, respectively. At levels $\geq 38$ times higher than human exposure doses, adefovir given intravenously to pregnant rats was associated with increased fetal malfor- mations like anasarca, depressed eye bulge, umbilical hernia and kinked tail. ${ }^{90}$ There are few case reports in the APR on adefovir (48 cases). ${ }^{73}$

\section{Interferons}

There have been no clinical studies of interferons in pregnancy; therefore, the safety in this setting has not been established. This, together with its very limited data in animal studies, means that its use is not advised, especially given its known antiproliferative effects. ${ }^{91}$

\section{PREVENTION OF HEPATITIS B VIRUS TRANSMISSION TO THE NEWBORNS}

\section{Prenatal (Antepartum) Stage Interventions Hepatitis B Immunoglobulin Injection}

Although earlier reports showed that antepartum HBIg induced drop in maternal HBV DNA was associated with a modest reduction of mother to infant transmission rates, ${ }^{92-94}$ recent randomized controlled trial from China showed that antepartum HBIg use was not effective in preventing mother to infant transmission. ${ }^{95}$ In addition, all newborns from mothers who received antepartum HBIg were negative for anti-HBs at birth in this study, further challenging the hypothesis that HBIg transferred to the fetus would confer passive immunity to the newborn.

\section{Antivirals}

Approximately $10 \%$ of the offspring of HBV carriers are chronic hepatitis B sufferers in their early life even though they received routine neonatal immunoprophylaxis because they were infected in utero [see above]. The most important determinant of prophylaxis failure has been shown to be maternal serum HBV DNA levels (viral load) [see above].

One strategy for reducing vertical transmission of HBV infection is administering antivirals during pregnancy. Lamivudine was the first drug to be used in such a strategy.

A meta-analysis of 10 randomized clinical trials (RCTs) examining $951 \mathrm{HBV}$ carrier mothers was reported to evaluate the efficacy of lamivudine in reducing in utero transmission of HBV. ${ }^{28}$ The RCTs evaluated included newborns who received immunoprophylaxis at birth and women who were treated with lamivudine from 24 to 32 weeks of gestation, until delivery to 1 month post-delivery. Newborns in the lamivudine group had a 13-24\% significantly lower incidence of intrauterine exposure and a lower perinatal infection rate at 9-12 months. This report was limited by the quality of the studies included. ${ }^{28}$ However, a recent study showed that although the therapy with lamivudine achieved an HBV DNA load reduction of $3 \log 10 \mathrm{IU} / \mathrm{ml}$, in $20 \%$ of the pregnant women, the viral load remained high $\left(>1 \times 10^{7} \mathrm{IU} / \mathrm{ml}\right)$ and resistant mutations were detectable only after 3 months of therapy, 
calling for more potent antiviral drugs to be used to prevent transmission. ${ }^{96}$

Thus, although most experience is with lamivudine, the use of other nucleos( $\mathrm{t}$ )ide analogs may be more desirable for prevention of HBV transmission during pregnancy, given the high resistance rate with use of lamivudine. Each of the oral nucleos(t)ide analogs indicated for the management of HBV infection is listed as either a category $\mathrm{B}$ or a category $\mathrm{C}$ agent by the US Food and Drug Administration (FDA) (Table 1). Lamivudine, adefovir, and entecavir are designated category $\mathrm{C}$ drugs; telbivudine and tenofovir are category $\mathrm{B}$ drugs (Table 1 ).

One recently published study showed the efficacy of telbivudine $600 \mathrm{mg}$ per day in preventing mother to infant transmission when used during the second or third trimesters in highly viremic $\mathrm{HBeAg}$-positive mothers with $\mathrm{HBV}$ DNA $>6 \log 10$ copies $(200,000 \mathrm{IU}) / \mathrm{mL}^{.97}$ The study showed that telbivudine plus vaccination is superior to HBIg and HBV vaccines only in newborns to prevent HBV transmission ( $0 \%$ vs $8 \%$ ). In this trial, no measurable differences in adverse events or congenital deformities were observed for mothers or newborns when the treatment and control groups were compared up to 28 weeks after birth. This study reconfirms data from a recent study of 31 pregnant women in China, treated with telbivudine started at weeks $28-32$ of pregnancy and continued to 30 days postpartum. ${ }^{98}$ All babies received active and passive immunoprophylaxis. The infection rate was $0 \%$ in those treated with telbivudine and $13.3 \%$ in the untreated controls. $^{98}$

Currently, there are no prospective studies published for the use of tenofovir in pregnant women with HBV monoinfection. However, as a pregnancy category B medication, tenofovir has been safely used in pregnant women with HIV (some with HBV co-infection) [see above]. Entecavir and adefovir are not recommended for pregnant women [see above].

\section{Natal (Intrapartum) Stage Interventions Caesarian Section or Instrument Assisted Delivery}

With regard to mothers to infant transmission of HBV during delivery, disagreements still exist on the issue of whether different mode of delivery (mainly caesarean section versus vaginal delivery) will affect the risk of mother to infant HBV transmission. Of the cases of mothers to infant transmission of $\mathrm{HBV}$, a large proportion occurs during the intrapartum period. Underlying mechanisms may include transfusion of the mother's blood to the fetus during labor contractions, infection after the rupture of membranes, and direct contact of the fetus with infected secretions or blood from the maternal genital tract. In a recent meta-analysis [four randomized trails involving 789 people were included], there was strong evidence that elective caesarian section (ECS) versus vaginal delivery could effectively reduce the rate of mothers to infant transmission of HBV (ECS: $10.5 \%$; vaginal delivery: $28.0 \%$ ). The difference between the two groups (elective caesarian section versus vaginal delivery) had statistical significance (Relative risk (RR) $0.41,95 \%$ CI $0.28-0.60, P<0.001) .{ }^{99}$ However, methodological concerns including lack of information on randomization procedure, lack of allocation concealment, and lack of blinding, make the role of elective caesarian section for preventing mother to infant transmission of HBV uncertain. More high quality controlled trials are required for assessing the effects of elective caesarian section in comparison to vaginal delivery for preventing mothers to infant transmission of HBV. In addition, elective CS has to be performed before the onset of labor or before the rupture of membranes to achieve effectiveness. ${ }^{99}$ At this point, most obstetrical algorithms do not include change in the planned mode of delivery for $\mathrm{HBsAg}$ positive women regardless of $\mathrm{HBeAg}$ status or level of viremia. ${ }^{99}$ Current available data did not show any association between the risk of transmission and forceps/vacuum extraction during delivery. ${ }^{100}$

\section{Postnatal (Postpartum) Stage Interventions Immunization}

In a recent meta-analysis of clinical trials, the relative risk of neonatal $\mathrm{HBV}$ infection in those who received $\mathrm{HBV}$ vaccine (plasma-derived or recombinant) was 0.28 [95\% confidence interval (CI) 0.2-0.4] compared with those who received placebo or no intervention. Compared with vaccine alone, the addition of HBIg to the regimen further reduced the relative risk $(0.54,95 \%$ CI $0.41-0.73)$ when compared with active prophylaxis only. ${ }^{101}$ Passive-active immunization with $\mathrm{HBV}$ vaccine and HBIg administered 12-24 $\mathrm{h}$ after birth, followed by completion of a 3-dose vaccine series, has been demonstrated to be $85 \%-95 \%$ effective in preventing acute and chronic HBV infection in infants born to women who are positive for both HBsAg and HBeAg. ${ }^{102}$ Although clinical trials have evaluated the efficacy of passive-active immunization with $\mathrm{HBV}$ vaccine and HBIg administered only within $24 \mathrm{~h}$ of birth, studies of passive immunoprophylaxis have demonstrated that HBIg provided protection when administered as late as $72 \mathrm{~h}$ after exposure. Infants born to HBsAg-positive/ HBeAg-negative mothers who receive passive-active immunization with $\mathrm{HBIg}$ and $\mathrm{HBV}$ vaccine are expected to should have the same high degree of protection as infants born to women who are HBsAg positive/HBeAg positive.

Active immunization $\mathrm{HBV}$ vaccine alone (i.e., without HBIg) may be used in certain remote areas where implementation of maternal HBsAg testing is difficult because no access exists to a laboratory. In randomized, placebocontrolled clinical trials, administration of hepatitis $B$ vaccine in a 3- or 4-dose schedule without HBIg beginning $\leq 12 \mathrm{~h}$ after birth has been demonstrated to prevent 
70\%-95\% of perinatal HBV infections among infants born to women who are positive for both HBsAg and HBeAg. ${ }^{103,104}$ Population-based studies in areas with a high endemicity of $\mathrm{HBV}$ infection have demonstrated that active immunization is highly effective in preventing infection when the first dose is administered soon after birth, the second at age 1-2 months, and the third at age 6-8 months. ${ }^{105-107}$

All pregnant women should be tested routinely for HBsAg during an early prenatal visit (e.g., first trimester) in each pregnancy, even if they have been previously vaccinated or tested. Women who were not screened prenatally, those who engage in behaviors that put them at high risk for infection (e.g., injection-drug use, having had more than one sex partner in the previous 6 months or an HBsAg-positive sex partner, evaluation or treatment for a sexually transmitted disease, or recent or current injection-drug use) and those with clinical hepatitis should be tested at the time of admission to the hospital for delivery. ${ }^{108}$

\section{CHRONIC HEPATITIS B VIRUS INFECTION AND BREASTFEEDING}

\section{Benefits of Breastfeeding}

Breastfeeding in general has short- and long-term benefits both for mothers and children. Breastfeeding, leads to significant reduction in hospitalization rates for gastroenteritis, respiratory infections, and sepsis in the early months of life. ${ }^{109}$ In low-resource countries, breastfeeding has been related to better infant and childhood survival. $^{110,111}$

For older children, role of prolonged breastfeeding in development of cognitive functions has been proposed. $^{112,113}$ For older children and adults, a possible impact of breastfeeding on cholesterol levels, body mass index, obesity and type 2 diabetes. ${ }^{114,115}$ The benefits of breastfeeding for mothers are well known. Oxytocinstimulated uterus contraction prevents anemia. Lactation-induced suppression of ovulation has contraceptive effect during the period of exclusive breastfeeding. Lactating women seem to regain their pre-pregnant weight sooner, and in the long-term have reduced obesity risk. The risks of breast and ovarian cancer and osteoporosis are also decreased. ${ }^{116-119}$ Besides all these, breastfeeding enhances emotional bonding and close mother to infant contact.

\section{Chronic Hepatitis B Virus Infected Mother and Safety of Breastfeeding}

HBsAg, HBeAg and HBV DNA have been detected in breast milk. ${ }^{116,120,121}$ Also both colostral HBsAg and HBeAg titers correlate positively with the corresponding levels in the maternal blood. ${ }^{122}$ In Chinese studies, HBV DNA has been detected in 76.9-81.25\% breast milk of mothers if mothers were HBsAg and HBeAg were positive and in $5.75-45.24 \%$ if $\mathrm{HBeAg}$ was negative. ${ }^{123,124}$ In a recent meta-analysis based on 32 studies, it was found that the difference in risk of the infection between breastfed and formula-fed infants born to chronic HBVinfected mothers was $-0.8 \%$ (95\% confidence interval [CI]: $-1.6 \%, 0.1 \%)$. Furthermore, analysis of the data from 16 of the studies found that difference in risk of the infection between breastfed and formula-fed infants for mothers who are positive for the HBeAg and/or the HBV DNA, was similar to that for those who are negative for these infectivity markers [0.7\% (95\% CI: $-2.0 \%, 3.5 \%)$ vs $-0.5 \%$ (95\%CI: $-1.7 \%, 0.6 \%), \mathrm{P}=\mathrm{ns}]$. Thus, although breast milk is infectious; yet, breastfeeding, even by mothers with high infectivity, is not associated with demonstrable risk of infantile chronic HBV infection, provided that the infants have been vaccinated against $\mathrm{HBV}$ at birth. ${ }^{125}$ Even in cases of no active or passive prophylaxis, the risk of transmission from $\mathrm{HBV}$-positive mothers to their breastfed infants is the same. ${ }^{70}$ Bacteriostatic, bactericidal and antiviral activities of lactoferrin are well known. ${ }^{116}$ Recent studies have also shown anti-HBV effects of lactoferrin. ${ }^{126,127}$

Benefits of exclusive breastfeeding in reducing HIV transmission has been suggested. Small changes in the rate of suckling or non-exclusive breastfeeding could be associated with milk stasis and breast engorgement. If not reversed in a short time, the epithelial permeability might increase (leaky tight junctions). ${ }^{116}$ This phenomenon allows more efficient paracellular transfer of HIV and increased HIV RNA in breast milk. ${ }^{128,129}$ Thus, irregular or non-exclusive breastfeeding might contribute to increased infectivity of human milk. It is unknown if a similar situation could exist for HBV also and requires further studies. This issue is of considerable importance for high-prevalence regions with low social standards where promotion of exclusive breastfeeding is vital for child morbidity and mortality. ${ }^{116}$

\section{Antivirals and Breastfeeding}

The period immediately after birth is a time of treatment uncertainty in mothers who choose to breastfeed, because nucleoside analogs are likely to pass into the breast milk to some degree, and it is probably unwise to expose the child in this manner. ${ }^{116,130}$

\section{Lamivudine}

Lamivudine is found in higher concentrations in human breast milk than serum. ${ }^{131}$ However, given the actual concentration, coupled with the average volume of feed ingested by an infant, suggest that amount of drug the infant would be exposed to via this route is negligible compared to standard oral dosing. ${ }^{132}$ In one recent study, the median breast milk concentration of lamivudine in 67 HIV-infected women treated with a combination of lamivudine, zidovudine and nevirapine was $1214 \mathrm{ng} / \mathrm{ml}$ 
compared to $508 \mathrm{ng} / \mathrm{ml}$ in maternal plasma (breast milk to plasma ratio 2.56). ${ }^{133}$

\section{Tenofovir}

Tenofovir is present at low concentrations in human breast milk. ${ }^{134}$ But its oral bioavailability is limited and thus infants are exposed to only small concentrations. ${ }^{134}$

\section{Telbivudine}

Data on human placental passage and breast milk excretion are not available.

\section{Entecavir}

Entecavir monohydrate or its conjugate metabolites are excreted in milk of rats, but it is not known whether human breast milk excretion occurs.

\section{Adefovir}

It is not known whether adefovir is excreted in human or animal milk.

European Association for the Study of the Liver (EASL) 2012 guidelines recommend that HBsAg can be detected in breast milk, but breastfeeding may not be considered a contraindication in HBsAg-positive mothers. The safety of nucleot(s)ide analog (NA) therapy during lactation is uncertain. $^{135}$

\section{MANAGEMENT OF CHBV INFECTION IN WOMEN WHO DESIRE PREGNANCY}

EASL 2012 guidelines recommends that family planning should be always discussed with women of childbearing age before initiating HBV therapy. The woman should be informed about the safety data of the drugs on a possible pregnancy (A1). In a woman of childbearing age without advanced fibrosis who plans a pregnancy in the near future, it may be prudent to delay therapy until the child is born (C1). In a woman of childbearing age with advanced fibrosis or cirrhosis who agrees for a "planned pregnancy" in the future, pegylated interferon (PEG-IFN) therapy may be tried as it is given for a finite duration (C1). It should be noted that effective contraception is required during (PEG)IFN therapy. If PEG-IFN is not possible or has failed, treatment with a nucleot(s)ide analog (NA) has to be initiated and maintained even during a future pregnancy (C1). Tenofovir represents the most reasonable choice for such female patients (B1). ${ }^{135}$

The Asian Pacific Association for the Study of the Liver (APASL) 2012 guidelines recommends that for female patients of childbearing age, IFN-based therapy is preferred for nonpregnant women. Pregnancy is discouraged during IFN therapy (IA). Pregnant women who need treatment can be treated with category B nucleot(s)ide analog (NA) (IIA). ${ }^{136}$ Figure 1 shows the approach to women with chronic HBV infection who desire pregnancy.

\section{MANAGEMENT OF CHBV INFECTION IN WOMEN WHO BECOME PREGNANT WHILE TAKING ANTIVIRALS OR ARE FIRST DETECTED DURING PREGNANCY}

If a pregnancy occurs in a woman already receiving a medication for HBV, decisions must be individualized. When a woman on HBV antiviral therapy becomes pregnant, decision has to be taken whether to continue therapy in pregnancy or withdraw therapy immediately. In this regard, health of the mother and the fetus must be considered independently. Fetal concerns are regarding the risk of exposure to medication during early embryogenesis. From fetal point of view, withdrawal during pregnancy is preferable, especially to the mother who wants to avoid any potential future risk to the fetus. Maternal concerns include whether stopping or changing medication will adversely affect both short- and long-term liver disease outcomes. First decision to be made is if the antiviral treatment can be stopped completely. Data specifically addressing the risk of stopping therapy during pregnancy are not available. In early antiviral studies in nonpregnant, therapy was stopped after completion of the trial, even for patients who remained $\mathrm{HBeAg}$ positive. In general, if mild fibrosis is there, HBV DNA levels rebound, but clinically significant flares of hepatitis have been rare; but in cases of advanced fibrosis or cirrhosis, flares upon treatment withdrawal can result in decompensation. ${ }^{137-139}$ Overall, it appears the risk of an adverse outcome with continuing antiviral therapy during pregnancy is likely very low. However, therapy could be discontinued with close observation of the mother to avoid continued fetal exposure during the first trimester, especially in the patient who does not have advanced fibrosis (Figure 2).

EASL 2012 guidelines recommend that, if female patients become pregnant during anti-HBV therapy, treatment indications should be reevaluated (C1). Patients with advanced fibrosis or cirrhosis should definitely continue to be treated, but the treating agent should be reconsidered (C1). PEG-IFN must be stopped and the patients should continue on a NA, while FDA category C NAs, particularly adefovir and entecavir, should be changed to a FDA category B NA (C1). Among FDA category B NAs, tenofovir is preferred because of its high potency, high genetic barrier and available safety data in pregnancy (C1). ${ }^{135}$ The same treatment indications apply to women who are first diagnosed to have chronic HBV infection during pregnancy (Figure 3), with patients with advanced fibrosis or cirrhosis should be started on treatment with appropriate NAs. ${ }^{135}$

All patients should have HBV DNA levels repeated in last trimester. The prevention of mother to infant transmission, which is considered to occur mainly at delivery, is traditionally based on the combination of passive and active immunization with hepatitis $\mathrm{B}$ immunoglobulin 
(HBIg) and HBV vaccination. Such a strategy, however, may not be effective in a proportion of newborns from highly viremic (serum HBV DNA $>10^{6-7} \mathrm{IU} / \mathrm{ml}$ ). Mothers with these high concentrations of HBV DNA should be informed that utilizing a NA to reduce their viral loads could add to the effectiveness of HBIg and vaccination (B1). Lamivudine and recently telbivudine therapy during the last trimester of pregnancy in pregnant HBsAg-positive women with high levels of viremia have been shown to be safe and to reduce the risk of intrauterine and perinatal transmission of $\mathrm{HBV}$ if given in addition to passive and active vaccination by HBIg and HBV vaccination (B1). Thus, telbivudine, lamivudine or tenofovir (as a potent FDA category $\mathrm{B}$ agent) may be used for the prevention of perinatal and intrauterine HBV transmission in the last trimester of pregnancy in HBsAg-positive women with high levels of viremia (serum HBV DNA $>10^{6-7} \mathrm{IU} / \mathrm{ml}$ ) (B1). No controlled clinical trial of tenofovir to prevent perinatal transmission has been conducted. If NA therapy is given only for the prevention of perinatal transmission, it may be discontinued within the first 3 months after delivery (C1). APASL 2012 guideline recommends that for the prevention of mother to infant transmission, pregnant women with high HBV DNA $\left(>2 \times 10^{6} \mathrm{IU} / \mathrm{mL}\right)$ can be treated with telbivudine in the third trimester (IIA). Tenofovir is an alternative (IIIA). ${ }^{136}$ Although different maternal HBV DNA thresholds have been suggested for antiviral use in last trimester, the recent Chinese study found that HBV immunoprophylaxis failure occurred among infants born to HBeAg-positive mothers with HBV DNA levels $>6 \log 10$ copies/mL and no immunoprophylaxis failure occurred in infants born to the mothers who were HBeAg negative or had HBV DNA levels $<6 \log 10$ copies/mL. This study also found that 81 percent of the infants with immunoprophylaxis failure were born to the mothers with DNA levels between 6 and $7 \log 10$ copies/mL. ${ }^{34}$ In view of these findings, it seems reasonable to use $6 \log 10$ copies / $\mathrm{mL}$ as the threshold for maternal antiviral treatment during last trimester with the aim to interrupt mother to infant transmission.

EASL 2012 guidelines recommend that if a pregnant woman remains untreated or anti-HBV therapy is discontinued during pregnancy or early after delivery for any reason, close monitoring of the patient is necessary, as there is a risk of hepatic flares, especially after delivery (B1). ${ }^{135}$

\section{SUMMARY}

Chronic HBV infection is usually mild in pregnant women, but may flare shortly after delivery. Effect of HBV infection on pregnancy outcomes is generally favorable, but may depend on severity of liver disease. All decisions about initiating, continuing, or stopping therapy of the chronic hepatitis B virus infection during pregnancy must include an analysis of the risks and benefits for mother and fetus.
Mother to infant transmission can be minimized by current immunoprophylaxis strategies, however high levels of viremia in mothers may be a factor in the failure of current immunoprophylaxis strategies. Antiviral therapy during late stages of pregnancy is the most effective method to reduce transmission from mothers with high levels of viremia. Use of antivirals during pregnancy needs to be individualized. Breastfeeding, is generally not recommended while receiving antiviral therapy.

\section{CONFLICTS OF INTEREST}

All authors have none to declare.

\section{REFERENCES}

1. Kumar M, Sarin SK, Hissar S, et al. Virological and histological features of chronic hepatitis B virus infected asymptomatic patients with persistently normal ALT. Gastroenterology. 2008;134(5):1376-1384.

2. Lavanchy D. Hepatitis B virus epidemiology, disease burden, treatment, and current and emerging prevention and control measures. J Viral Hepat. 2004;11:97-107.

3. Gambarin-Gelwan M. Hepatitis B in pregnancy. Clin Liver Dis. 2007;11:945-963.

4. Beasley RP, Trepo C, Stevens CE, Szmuness W. The e antigen and vertical transmission of hepatitis B surface antigen. Am J Epidemiol. 1977;105:94-98.

5. Lodha R, Jain Y, Anand K, Kabra SK, Pandav CS. Hepatitis B in India. A review of disease epidemiology. Indian Pediatr. 2001;38:349-371.

6. Arora NK, Kant L, Mathur P. Transmission of hepatitis B virus in children. In: Sarin SK, Singal AK, eds. Hepatitis B in India Prevention and Management. 1st ed. New Delhi: CBS Publishers and Distributors; 2004:29-45.

7. Prakash C, Sharma RS, Bhatia R, Verghese T, Datta KK. Prevalence of North India of hepatitis B carrier state amongst pregnant women. Southeast Asian J Trop Med Public Health. 1998;29(1): 80-84.

8. Nayak NC, Panda SK, Zuckerman AJ, Bhan MK, Guha DK. Dynamics and impact of perinatal transmission of hepatitis $B$ virus in North India. J Med Virol. 1987;21:137-145.

9. Panda SK, Ramesh R, Rao KV, Gupta A, Zuckerman AJ, Nayak NC. Comparative evaluation of the immunogenicity of yeast-derived (recombinant) and plasma-derived hepatitis $B$ vaccine in infants. J Med Virol. 1991;35:297-302.

10. Gill HH, Majumdar PD, Dhunjibhoy KR, Desai HG. Prevalence of hepatitis $B$ e antigen in pregnant women and patients with liver disease. J Assoc Physicians India. 1995;43:247-248.

11. Mittal SK, Rao S, Rastogi A, Aggarwal V, Kumari S. Hepatitis B: potential of perinatal transmission in India. Trop Gastroenterol. 1996;17:190-192.

12. Chatterjee S, Ravishankar K, Chatterjee R, Narang A, Kinikar A. Hepatitis B prevalence during pregnancy. Indian Pediatr. 2009;46(11):1005-1008.

13. Dwivedi M, Misra SP, Misra V, et al. Seroprevalence of hepatitis B infection during pregnancy and risk of perinatal transmission. In dian J Gastroenterol. 2011;30(2):66-71.

14. Pande C, Sarin SK, Patra S, et al. Prevalence, risk factors and virological profile of chronic hepatitis $B$ virus infection in pregnant women in India. J Med Virol. 2011;83(6):962-967.

15. Mahtab MA, Rahman S, Khan M, Mamun AA, Afroz S. Etiology of fulminant hepatic failure: experience from a tertiary hospital in Bangladesh. Hepatobiliary Pancreat Dis Int. 2008;7(2):161-164. 
16. Yang YB, Li XM, Shi ZJ, Ma L. Pregnant woman with fulminant hepatic failure caused by hepatitis $B$ virus infection: a case report. World J Gastroenterol. 2004;10(15):2305-2306.

17. ter Borg MJ, Leemans WF, de Man RA, Janssen HL. Exacerbation of chronic hepatitis B infection after delivery. J Viral Hepat. 2008;15(1):37-41.

18. Lin HH, Chen PJ, Chen DS, et al. Postpartum subsidence of hepatitis B viral replication in HBeAg-positive carrier mothers. $J$ Med Virol. 1989;29:1-6.

19. Lin HH, Wu WY, Kao JH, Chen DS. Hepatitis B post-partum e antigen clearance in hepatitis $B$ carrier mothers: correlation with viral characteristics. J Gastroenterol Hepatol. 2006;21:605-609.

20. Tagawa H, Suzuki K, Oh S, Kawano M, Fujita A, Yasuhi Y. Influence of pregnancy on HB virus carriers. Nippon Sanka Fujinka Gakkai Zasshi. 1987;39(1):24-30 [in Japanese].

21. Wong HY, Tan JYL, Lim CC. Abnormal liver function tests in the symptomatic pregnant patient: the local experience in Singapore. Ann Acad Med Singap. 2004;33:204-208.

22. Chisari FV, Ferrari C. Hepatitis B virus immunopathogenesis. Annu Rev Immunol. 1995;13:29-60.

23. Trowsdale J, Betz AG. Mother's little helpers: mechanisms of maternal-fetal tolerance. Nat Immunol. 2006;7(3):241-246.

24. Sinha S, Kumar M. Pregnancy and chronic hepatitis B virus infection. Hepatol Res. 2010;40(1):31-48.

25. Tse KY, Ho LF, Lao T. The impact of maternal HBsAg carrier status on pregnancy outcomes: a case-control study. J Hepatol. 2005;43(5):771-775.

26. Levy A, Sikuler E, Sheiner E. Maternal hepatitis B virus or hepatitis $C$ virus carrier status as an independent risk factor for adverse perinatal outcome. Liver Int. 2010;30(5):765-770.

27. Elefsiniotis IS, Tsoumakas K, Papadakis M, Vlachos G, Saroglou G, Antsaklis A. Importance of maternal and cord blood viremia in pregnant women with chronic hepatitis $B$ virus infection. Eur J Intern Med. 2011;22(2):182-186.

28. Shi Z, Yang Y, Ma L, Li X, Schreiber A. Lamivudine in late pregnancy to interrupt in utero transmission of hepatitis B virus: a systematic review and meta-analysis. Obstet Gynecol. 2010;116:147-159.

29. Sarin SK, Kumar M, Shrivastava S, Sinha S, Pati NT. Influence of chronic HBV infection on pregnancy: a human model of maternofetal virus host interactions. Gastroenterology. 2011;141(4): 1522-1525.

30. Chen $\mathrm{HL}$, Chang $\mathrm{CJ}$, Kong MS, et al. Fulminant hepatic failure in children in endemic area of hepatitis B virus infection: 15 years after universal hepatitis B vaccination. Hepatology. 2004;39: 58-63.

31. Wang JS, Chen H, Zhu QR. Transformation of hepatitis B serologic markers in babies born to hepatitis B surface antigen positive mothers. World J Gastroenterol. 2005;11:3582-3585.

32. Xu DZ, Yan YP, Choi BC, et al. Risk factors and mechanism of transplacental transmission of hepatitis B virus: a case-control study. J Med Virol. 2002;67:20-26.

33. Wiseman E, Fraser MA, Holden S, et al. Perinatal transmission of hepatitis B virus: an Australian experience. Med J Aust. 2009;190:489-492.

34. Zou H, Chen Y, Duan Z, Zhang H, Pan C. Virologic factors associated with failure to passive-active immunoprophylaxis in infants born to HBsAg-positive mothers. J Viral Hepat. 2012;19(2):e18-e25.

35. Wang Z, Zhang J, Yang $\mathrm{H}$, et al. Quantitative analysis of HBV DNA level and $\mathrm{HBeAg}$ titer in hepatitis B surface antigen positive mothers and their babies: HBeAg passage through the placenta and the rate of decay in babies. J Med Virol. 2003;71(3):360366.

36. Chang MH, Hsu HY, Huang LM, Lee PI, Lin HH, Lee CY. The role of transplacental hepatitis $B$ core antibody in the mother- to-infant transmission of hepatitis B virus. J Hepatol. 1996;24(6):674-679.

37. Burk RD, Hwang LY, Ho GY, Shafritz DA, Beasley RP. Outcome of perinatal hepatitis $B$ virus exposure is dependent on maternal virus load. J Infect Dis. 1994;170:1418-1423.

38. del Canho R, Grosheide PM, Schalm SW, de Vries RR, Heijtink RA. Failure of neonatal hepatitis $B$ vaccination: the role of HBV-DNA levels in hepatitis B carrier mothers and HLA antigens in neonates. J Hepatol. 1994;20:483-486.

39. Singh AE, Plitt SS, Osiowy $C$, et al. Factors associated with vaccine failure and vertical transmission of hepatitis B among a cohort of Canadian mothers and infants. I Viral Hepat. 2011;18(7):468-473.

40. Pande C, Kumar A, Patra S, Trivedi SS, Dutta AK, Sarin SK. High Maternal Hepatitis B Virus DNA Levels but Not HBeAg Positivity Predicts Perinatal Transmission of Hepatitis $B$ to the Newborn. DDW; 2008. A252.

41. Milich D, Liang TJ. Exploring the biological basis of hepatitis B e antigen in hepatitis B virus infection. Hepatology. 2003;38: 1075-1086.

42. Nie R, Jin L, Zhang H, Xu B, Chen W, Zhu G. Presence of hepatitis B virus in oocytes and embryos: a risk of hepatitis $B$ virus transmission during in vitro fertilization. Fertil Steril. 2011;95:1667-1671.

43. Yu H, Zhu QR, Gu SQ, Fei LE. Relationship between IFN-gamma gene polymorphism and susceptibility to intrauterine HBV infection. World J Gastroenterol. 2006;12:2928-2931.

44. Zhang SL, Han XB, Yue YF. Relationship between HBV viremia level of pregnant women and intrauterine infection: nested PCR for detection of HBV DNA. World J Gastroenterol. 1998;4: 61-63.

45. Kew MC, Kassianides C, Berger EL, Song E, Dusheiko GM. Prevalence of chronic hepatitis $B$ virus infection in pregnant black women living in Soweto. J Med Virol. 1987;22:263-268.

46. Kao JH, Chen PJ, Lai MY, Chen DS. Clinical and virological aspects of blood donors infected with hepatitis $\mathrm{B}$ virus genotypes $\mathrm{B}$ and $\mathrm{C}$. J Clin Microbiol. 2002;40:22-25.

47. Chu CJ, Hussain M, Lok ASF. Hepatitis B virus genotype B is associated with earlier $\mathrm{HBeAg}$ seroconversion compared with hepatitis B virus genotype C. Gastroenterology. 2002;122:1756-1762.

48. Candotti D, Opare-Sem O, Rezvan H, Sarkodie F, Allain JP. Molecular and serological characterization of hepatitis B virus in deferred Ghanaian blood donors with and without elevated alanine aminotransferase. J Viral Hepat. 2006;13:715-724.

49. Inui A, Komatsu H, Sogo T, Nagai T, Abe K, Fujisawa T. Hepatitis B virus genotypes in children and adolescents in Japan: before and after immunization for the prevention of mother to infant transmission of hepatitis B virus. J Med Virol. 2007;79(6):670-675.

50. Liu SL, Dong Y, Zhang L, et al. Influence of HBV gene heterogeneity on the failure of immunization with HBV vaccines in eastern China. Arch Virol. 2009;154:437-443.

51. Hsu HY, Chang MH, Ni YH, Chen HL. Survey of hepatitis B surface variant infection in children 15 years after a nationwide vaccination programme in Taiwan. Gut. 2004;53:1499-1503.

52. Terazawa S, Kojima M, Yamanaka T, et al. Hepatitis B virus mutants with precore-region defects in two babies with fulminant hepatitis and their mothers positive for antibody to hepatitis B e antigen. Pediatr Res. 1991;29:5-9.

53. Raimondo G, Pollicino T, Cacciola I, Squadrito G. Occult hepatitis B virus infection. J Hepatol. 2007;46(1):160-170.

54. Coffin CS, Michalak TI. Persistence of infectious hepadnavirus in the offspring of woodchuck mothers recovered from viral hepatitis. J Clin Invest. 1999;104:203-212.

55. Saito T, Shinzawa H, Uchida T, et al. Quantitative DNA analysis of low-level hepatitis $B$ viremia in two patients with serologically negative chronic hepatitis B. J Med Virol. 1999;58:325-331. 
56. Kwon $\mathrm{Cl}$, Hwang SG, Shin SJ, et al. Occult hepatitis B virus infection in pregnant woman and its clinical implication. Liver Int. 2008;28(5):667-674.

57. Liu Y, Kuang J, Zhang R, Lin S, Ding H, Liu X. Analysis about clinical data of intrauterine infection of hepatitis $B$ virus. Zhonghua Fuchanke Zazhi. 2002;37:465-468.

58. Zhang SL, Yue YF, Bai GQ, Shi L, Jiang H. Mechanism of intrauterine infection of hepatitis B virus. World J Gastroenterol. 2004;10:437-438.

59. Bai H, Zhang L, Ma L, Dou XG, Feng GH, Zhao GZ. Relationship of hepatitis $B$ virus infection of placental barrier and hepatitis $B$ virus intrauterine transmission mechanism. World J Gastroenterol. 2007;13:3625-3630.

60. Lin HH, Lee TY, Chen DS, et al. Transplacental leakage of HBeAg-positive maternal blood as the most likely route in causing intrauterine infection with hepatitis B virus. J Pediatr. 1987;111: 877-881.

61. Towers CV, Chinn DH, Asrat T, Miller El, Freeman RK. Intraamniotic bleeding following transabdominal amniocentesis. J Matern Fetal Med. 1993;2:133-137.

62. Ko TM, Tseng LH, Chang MH, et al. Amniocentesis in mothers who are hepatitis $B$ virus carriers does not expose the infant to an increased risk of hepatitis B virus infection. Arch Gynecol Obstet. 1994;255(1):25-30.

63. Alexander JM, Ramus R, Jackson G, Sercely B, Wendel Jr GD. Risk of hepatitis $B$ transmission after amniocentesis in chronic hepatitis B carriers. Infect Dis Obstet Gynecol. 1999;7(6):283-286.

64. Towers CV, Asrat T, Rumney P. The presence of hepatitis B surface antigen and deoxyribonucleic acid in amniotic fluid and cord blood. Am J Obstet Gynecol. 2001;184:1514-1520.

65. Bai GQ, Li SH, Yue YF, Shi L. The study on role of peripheral blood mononuclear cell in HBV intrauterine infection. Arch Gynecol Obstet. 2011;283:317-321.

66. Zhu QR, Ge YL, Gu SQ, et al. Relationship between cytokines gene polymorphism and susceptibility to hepatitis $B$ virus intrauterine infection. Chin Med J. 2005;118:1604-1609.

67. Wong VC, Lee AK, Ip HM. Transmission of hepatitis B antigens from symptom free carrier mothers to the fetus and the infant. Br J Obstet Gynaecol. 1980;87:958-965.

68. Pao CC, Yao DS, Lin MY, Lin CY, Hsieh TT. Hepatitis B virus DNA in cervicovaginal cells. Arch Pathol Lab Med. 1991;115:607-609.

69. Beasley RP, Stevens CE, Shiao IS, Meng HC. Evidence against breastfeeding as a mechanism for vertical transmission of hepatitis B. Lancet. 1975;2:740-741.

70. De Martino M, Appendino C, Resti M, Rossi ME, Muccioli AT, Vierucci A. Should hepatitis B surface antigen positive mothers breast feed? Arch Dis Child. 1985;60:972-974.

71. Hill JB, Sheffield JS, Kim MJ, Alexander JM, Sercely B, Wendel GD. Risk of hepatitis $B$ transmission in breast-fed infants of chronic hepatitis B carriers. Obstet Gynecol. 2002;99:1049-1052.

72. Wang JS, Zhu QR, Wang XH. Breastfeeding does not pose any additional risk of immunoprophylaxis failure on infants of HBV carrier mothers. Int J Clin Pract. 2003;57:100-102.

73. APR. Available at: http://www.APregistry.com. Interim report January 1, 1989 through January 31, 2012. Antiviral Pregnancy Registry, 2011. Accessed June 2012.

74. Gibb DM, Kizito H, Russell EC, et al, on behalf of the DART trial team. Pregnancy and infant outcomes among HIV-Infected women taking long-term ART with and without tenofovir in the DART trial. PLoS Med. 2012;9(5):e1001217.

75. Bloom SL, Dias KM, Bawdon RE, Gilstrap 3rd LC. The maternalfetal transfer of lamivudine in the ex vivo human placenta. Am J Obstet Gynecol. 1997;176(2):291-293.

76. Mandelbrot L, Peytavin G, Firtion G, Farinotti R. Maternal-fetal transfer and amniotic fluid accumulation of lamivudine in human immunodeficiency virus-infected pregnant women. Am J Obstet Gynecol. 2001;184(2):153-158.

77. 3TC (Lamivudine). Product Information. Boronia, Victoria, Australia: GlaxoSmithKline; 2010.

78. Benhammou V, Warszawski J, Bellec S, et al, ANRS-Enquête Périnatale Française. Incidence of cancer in children perinatally exposed to nucleoside reverse transcriptase inhibitors. AIDS. 2008 Oct 18;22(16):2165-2177.

79. Hirt D, Urien S, Ekouevi DK, et al. Population pharmacokinetics of tenofovir in HIV-1-infected pregnant women and their neonates (ANRS 12109). Clin Pharmacol Ther. 2009;85:182-189.

80. Viread (Tenofovir Disoproxil Fumarate). Product Information. Foster City, CA, USA: Gilead Sciences; 2005.

81. Van Rompay KK, Durand-Gasselin L, Brignolo LL, et al. Chronic administration of tenofovir to rhesus macaques from infancy through adulthood and pregnancy: summary of pharmacokinetics and biological and virological effects. Antimicrob Agents Chemother. 2008;52:3144-3160.

82. Tarantal AF, Castillo A, Ekert JE, Bischofberger N, Martin RB. Fetal and maternal outcome after administration of tenofovir to gravid rhesus monkeys (Macaca mulatta). J Acquir Immune Defic Syndr. 2002;29:207-220.

83. Van Rompay KK, Brignolo LL, Meyer DJ, et al. Biological effects of short-term or prolonged administration of 9-[2-(phosphonomethoxy) propyl]adenine (tenofovir) to newborn and infant rhesus macaques. Antimicrob Agents Chemother. 2003;48:14691487.

84. Judd A, Boyd KL, Stöhr W, et al. Effect of tenofovir disoproxil fumarate on risk of renal abnormality in HIV-1-infected children on antiretroviral therapy: a nested case-control study. AIDS. 2010;24: 525-534.

85. Riordan A, Judd A, Boyd K, et al. Tenofovir se in human immunodeficiency virus-1-infected children in the United kingdom and Ireland. Pediatr Infect Dis J. 2009;28:204-209.

86. Siberry GK, Williams PL, Mendez $\mathrm{H}$, et al. Safety of tenofovir use during pregnancy: early growth outcomes in HIV-exposed uninfected infants. AIDS. 2012 Jun 1;26(9):1151-1159.

87. Perinatal HIV Guidelines Working Group. Public Health Service Task Force Recommendations for Use of Antiretroviral Drugs in Pregnant HIV-infected Women for Maternal Health and Interventions to Reduce Perinatal HIV Transmission in the United States. Available: http://aidsinfo.nih.gov/ContentFiles/PerinatalGL.pdf; 2010. Accessed July 2012.

88. Bridges EG, Selden JR, Luo S. Nonclinical safety profile of telbivudine, a novel potent antiviral agent for treatment of hepatitis B. Antimicrob Agents Chemother. 2008 Jul;52(7):2521-2528.

89. Baraclude (Entecavir Monohydrate). Product Information. Princeton, NJ, USA: Bristol-Myer Squibb; 2010.

90. Hepsera (Adefovir Dipivoxil). Product Information. Foster City, CA, USA: Gilead Sciences; 2006.

91. Giles M, Visvanathan K, Sasadeusz J. Antiviral therapy for hepatitis B infection during pregnancy and breastfeeding. Antivir Ther. 2011;16(5):621-628.

92. Zhu Q, Yu G, Yu H, et al. A randomized control trial on interruption of HBV transmission in uterus. Chin Med J (Engl). 2003;116: 685-687.

93. Yue $Y$, Yang $X$, Zhang $S$. Prevention of intrauterine infection by hepatitis $B$ virus with hepatitis $B$ immune globulin: efficacy and mechanism. Chin Med J (Engl). 1999;112:37-39.

94. Li XM, Shi MF, Yang YB, et al. Effect of hepatitis B immunoglobulin on interruption of HBV intrauterine infection. World J Gastroenterol. 2004;10:3215-3217.

95. Yuan J, Lin J, Xu A, et al. Antepartum immunoprophylaxis of three doses of hepatitis $B$ immunoglobulin is not effective: a single centre randomized study. J Viral Hepat. 2006;13:597-604. 
96. Ayres A, Yuen L, Manoharan S, et al. Lamivudine in Late Pregnancy for Prevention of HBV Transmission: Effectiveness and Detection of Antiviral Resistance. J Hepatology. 2011;54(supp1): S295-S296.

97. Han G-R, Cao M-K, Zhao W, et al. A prospective open-label study for the efficacy and safety of telbivudine in pregnancy for the prevention of perinatal transmission of hepatitis $B$ virus to the infant. J Hepatol. 2011;55:1215-1221.

98. Zhang $L J$, Wang $L$. Blocking intrauterine infection by telbivudine in pregnant chronic hepatitis B patients. Zhonghua Gan Zang Bing Za Zhi. 2009;17:561-563 [in Chinese].

99. Yang J, Zeng XM, Men YL, Zhao LS. Elective caesarean section versus vaginal delivery for preventing mother to child transmission of hepatitis B virus - a systematic review. Virol J. 2008;5:100-107.

100. Wang J, Zhu Q, Zhang X. Effect of delivery mode on maternal infant transmission of hepatitis B virus by immunoprophylaxis. Chin Med $J$ (Engl). 2002;115:1510-1512.

101. Lee C, Gong Y, Brok J, Boxall EH, Gluud C. Effect of hepatitis B immunisation in newborn infants of mothers positive for hepatitis $B$ surface antigen: systematic review and metaanalysis. BMJ. 2006;332:328-336.

102. Andre FE, Zuckerman AJ. Review: protective efficacy of hepatitis B vaccines in neonates. J Med Virol. 1994;44:144-151.

103. Milne A, West DJ, Chinh DV, Moyes CD, Poerschke G. Field evaluation of the efficacy and immunogenicity of recombinant hepatitis $B$ vaccine without HBIG in newborn Vietnamese infants. $J$ Med Virol. 2002;67:327-333.

104. Assateerawatt A, Tanphaichitr VS, Suvatte V, In-Ngarm L. Immunogenicity and protective efficacy of low dose recombinant DNA hepatitis $B$ vaccine in normal and high-risk neonates. Asian Pac J Allergy Immunol. 1991;9:89-93.

105. Hsu HM, Chen DS, Chuang $\mathrm{CH}$, et al. Efficacy of a mass hepatitis $B$ vaccination program in Taiwan: studies on 3464 infants of hepatitis B surface antigen-carrier mothers. JAMA. 1988;260: 2231-2235.

106. Al Faleh FZ, Al Jeffri M, Ramia S, et al. Seroepidemiology of hepatitis $B$ virus infection in Saudi children 8 years after a mass hepatitis B vaccination programme. J Infect. 1999;38:167-170.

107. Harpaz R, McMahon BJ, Margolis HS, et al. Elimination of new chronic hepatitis $B$ virus infections: results of the Alaska immunization program. J Infect Dis. 2000;181:413-418.

108. Mast EE, Margolis HS, Fiore AE, et al, Advisory Committee on Immunization Practices (ACIP). A comprehensive immunization strategy to eliminate transmission of hepatitis B virus infection in the United States: recommendations of the Advisory Committee on Immunization Practices (ACIP) part 1: immunization of infants, children, and adolescents. MMWR Recomm Rep. 2005;54(RR-16):1-31.

109. Quigley MA, Kelly YJ, Sacker A. Breastfeeding and hospitalization for diarrheal and respiratory infection in the United Kingdom Millennium Cohort Study. Pediatrics. 2007;119:e837-e842.

110. Effect of breastfeeding on infant and child mortality due to infectious diseases in less developed countries: a pooled analysis. WHO Collaborative Study Team on the Role of Breastfeeding on the Prevention of Infant Mortality. Lancet. 2000;355:451-455.

111. Jones G, Steketee RW, Black RE, Bhutta ZA, Morris SS. How many child deaths can we prevent this year? Lancet. 2003;362:65-71.

112. Kramer MS, Aboud F, Mironova E, et al. Breastfeeding and child cognitive development: new evidence from a large randomized trial. Arch Gen Psychiatry. 2008;65:578-584.

113. Caspi A, Williams B, Kim-Cohen J, et al. Moderation of breastfeeding effects on the IQ by genetic variation in fatty acid metabolism. Proc Natl Acad Sci USA. 2007;104:18860-18865.

114. Koletzko B, von Kries R, Closa R, et al. Can infant feeding choices modulate later obesity risk? Am J Clin Nutr. 2009;89: 1502S-1508S.
115. Owen CG, Whincup PH, Kaye SJ, et al. Does initial breastfeeding lead to lower blood cholesterol in adult life? A quantitative review of the evidence. Am J Clin Nutr. 2008;88:305-314.

116. Petrova M, Kamburov V. Breastfeeding and chronic HBV infection: clinical and social implications. World J Gastroenterol. 2010;16(40):5042-5046.

117. Breast cancer and breastfeeding: collaborative reanalysis of individual data from 47 epidemiological studies in 30 countries, including 50302 women with breast cancer and 96973 women without the disease. Lancet. 2002;360:187-195.

118. Shantakumar S, Terry MB, Teitelbaum SL, et al. Reproductive factors and breast cancer risk among older women. Breast Cancer Res Treat. 2007;102:365-374.

119. Gwinn ML, Lee NC, Rhodes PH, Layde PM, Rubin GL. Pregnancy, breast feeding, and oral contraceptives and the risk of epithelial ovarian cancer. J Clin Epidemiol. 1990;43. 559-56827-29.

120. Linnemann Jr CC, Goldberg S. Letter: HBAg in breast milk. Lancet. 1974;2:155

121. Ma L, Zhao GZ, Liang ZL. Relationship between load of HBV-DNA in serum and breast milk for pregnant women and safety of breastfeeding. China J Mod Med. 2006;16(17):2581-2585.

122. Lin HH, Hsu HY, Chang MH, Chen PJ, Chen DS. Hepatitis B virus in the colostra of HBeAg-positive carrier mothers. J Pediatr Gastroenterol Nutr. 1993;17:207-210.

123. Yang D, Li Y, Song J. Significance of detection of HBV-DNA and CMV-DNA by polymerase chain reaction in screening mothers' milk. Hunan Yi Ke Da Xue Xue Bao. 1999;24(1):44-46 [Article in Chinese].

124. He JY, Zhang YH, Zhang YL, Huang HF. Instructional significance of HBV-DNA load in maternal milk on breastfeeding of postpartum women infected with HBV. Zhonghua Yu Fang Yi Xue Za Zhi. 2011;45(11):1004-1006 [Article in Chinese].

125. Zheng Y, Lu Y, Ye Q, etal. Should chronic hepatitis B mothers breastfeed? A meta analysis. BMC Public Health. 2011;11:502-512.

126. Li S, Zhou H, Huang G, Liu N. Inhibition of HBV infection by bovine lactoferrin and iron-, zinc-saturated lactoferrin. Med Microbiol Immunol. 2009;198(1):19-25.

127. Hara K, Ikeda M, Saito S, et al. Lactoferrin inhibits hepatitis B virus infection in cultured human hepatocytes. Hepatol Res. 2002;24(3):228.

128. Semba RD, Kumwenda N, Hoover DR, et al. Human immunodeficiency virus load in breast milk, mastitis, and mother-to child transmission of human immunodeficiency virus type $1 . J$ Infect Dis. 1999;180:93-98.

129. Thea DM, Aldrovandi G, Kankasa C, et al. Post-weaning breast milk HIV-1 viral load, blood prolactin levels and breast milk volume. AIDS. 2006;20:1539-1547.

130. Tran TT. Management of hepatitis B in pregnancy: weighing the options. Cleve Clin J Med. 2009;76(suppl 3):S25-S29.

131. Shapiro RL, Holland DT, Capparelli E, et al. Antiretroviral concentrations in breast-feeding infants of women in Botswana receiving antiretroviral treatment. J Infect Dis. 2005;192(5):720-727.

132. Moodley J, Moodley D, Pillay K, et al. Pharmacokinetics and antiretroviral activity of lamivudine alone or when coadministered with zidovudine in human immunodeficiency virus type 1-infected pregnant women and their offspring. J Infect Dis. 1998;178(5):1327-1333.

133. Mirochnick M, Thomas T, Capparelli E, et al. Antiretroviral concentrations in breast-feeding infants of mothers receiving highly active antiretroviral therapy. Antimicrob Agents Chemother. 2009;53(3):1170-1176.

134. Benaboud S, Pruvost A, Coffie PA, et al. Breast milk concentrations of tenofovir and emtricitabine in HIV-1 infected women in Abidjan TEmAA Step 2 (ANRS 12109). Antimicrob Agents Chemother. 2011;55:1315-1317. 
135. European Association for the Study of the Liver. EASL clinical practice guidelines: management of chronic hepatitis $B$ virus infection. J Hepatol. 2012;57(1):167-185.

136. Liaw YF, Kao JH, Piratvisuth $T$, et al. Asian-Pacific consensus statement on the management of chronic hepatitis B: a 2012 update. Hepatol Int. 2012;6:531-561.

137. Santantonio $T$, Mazzola $M$, lacovazzi $T$, et al. Long-term follow-up of patients with anti-HBe/HBV DNA-positive chronic hepatitis B treated for 12 months with lamivudine. J Hepatol. 2000;32(2):300-306.

138. Honkoop P, de Man RA, Niesters HG, Zondervan PE, Schalm SW. Acute exacerbation of chronic hepatitis $B$ virus infection after withdrawal of lamivudine therapy. Hepatology. 2000;32(3):635-639.

139. Lim SG, Wai CT, Rajnakova A, Kajiji T, Guan R. Fatal hepatitis B reactivation following discontinuation of nucleoside analogues for chronic hepatitis B. Gut. 2002;51(4):597-599. 